\title{
Subglacial hydrology at Rink Isbræ, West Greenland inferred from sediment plume appearance
}

\author{
Kristin M. SCHILD, Robert L. HAWLEY, Blaine F. MORRISS* \\ Dartmouth College, Hanover, NH 03755, USA \\ E-mail: Kristin.M.Schild.GR@dartmouth.edu
}

\begin{abstract}
Marine-terminating outlet glaciers discharge most of the Greenland ice sheet's mass through frontal ablation and meltwater runoff. While calving can be estimated by in situ and remote sensing observations, submarine melting and subglacial meltwater transport are more challenging to quantify. Here we investigate the subglacial hydrology of Rink Isbræ, a fast-flowing West Greenland tidewater glacier, using time-lapse photography, modeled runoff estimates and daily satellite imagery from 2007 to 2011. We find that sediment plumes appear episodically at four distinct locations across the terminus, and last between $\mathbf{2} \mathrm{h}$ and $17 \mathrm{~d}$. This suggests short-term variability in discharge and the existence of persistent pathways. The seasonal onset of sediment plumes occurs before supraglacial lake drainages, shortly after the onset of runoff, and only after the wintertime ice mélange has begun disintegrating. Plumes were also visible after the cessation of runoff ( $23 \pm 5 \mathrm{~d}$ ), which is indicative of subglacial storage. The lack of either a seasonal velocity change or a correspondence between meltwater availability and plume occurrence suggests that the subglacial system persists in a state of inefficient drainage. Subglacial hydrology at tidewater glaciers is of critical importance in understanding dynamics at the ice front.
\end{abstract}

KEYWORDS: plume, melt, subglacial hydrology, tidewater glacier, MODIS, Rink Isbræ, Greenland

\section{INTRODUCTION}

\section{Background}

Mass loss from the Greenland ice sheet has quadrupled over the last decade due to a combination of increased surface runoff from the ice-sheet periphery, increased frontal ablation (ice discharge and submarine melting) and widespread speed up at tidewater glacier termini (Van den Broeke and others, 2009; Shepherd and others, 2012). Concentrated at the ice-sheet margins (Schrama and Wouters, 2011; Ewert and Dietrich, 2012), this mass loss impacts both the ice and ocean by changing the hypsometry of the glacier (Benn and Evans, 2010), increasing submarine melt rates (Motyka and others, 2013; O'Leary and Christoffersen, 2013; Slater and others, 2015), and altering the salinity, temperature and circulation of fjord waters (Straneo and others, 2011; Motyka and others, 2013; Sciascia and others, 2013; Cowton and others, 2015). The increased ice flow speed at tidewater glaciers is thought to be caused by a number of factors including increased basal sliding due to the increase in meltwater runoff (Zwally and others, 2002; Andersen and others, 2011; Sole and others, 2011), changes in back stress as mélange composition and extent fluctuate (Amundson and others, 2010; Howat and others, 2010; Vieli and Nick, 2011), as well as submarine melting at the terminus (Rignot and others, 2010; Vieli and Nick, 2011; Straneo and Heimbach, 2013).

Surface and subglacial meltwater runoff is important in tidewater glacier systems. Runoff is predicted to increase as Greenland's climate continues to warm (Bamber and others, 2012) and consequently is expected to continue

\footnotetext{
* Present address: United States Army Corps of Engineers, Engineering Research and Development Center, Cold Regions Research and Engineering Laboratory, Hanover, NH 03755, USA.
}

influencing fjord circulation and submarine melting by enhancing the entrainment of warm ocean waters (e.g. Jenkins, 2011; Xu and others, 2012; Motyka and others, 2013; Straneo and Heimbach, 2013). As fresh meltwater enters the fjord at depth, it mixes with ambient ocean water as it moves along the terminus to the surface, concurrently melting the terminus face (submarine melting), altering the geometry, and, potentially, the calving style (Motyka and others, 2011; O'Leary and Christoffersen, 2013; Slater and others, 2015). Therefore, understanding subglacial water transport is critical in identifying meltwater controls on tidewater outlet glacier dynamics and freshwater delivery to the ocean. Furthermore, incorporating these drainage processes into coupled ice/climate, ice/ocean and ice/climate/ocean models will advance our understanding of the long-term influence of these processes on glacier stability.

\section{Subglacial hydrology}

Water beneath ice travels a tortuous path. Subglacial drainage efficiency is characterized by two endmember systems, distributed systems (inefficient) or channelized systems (efficient). Kamb (1987) hypothesized that a distributed subglacial hydraulic system initially consists of an inefficient network of linked basal cavities. This system can become more efficient under high water flow conditions. As more surface meltwater drains through the system, higher water flow would cause melting of the overlying ice, initiating an efficient channelized network of ice tunnels, known as R-channels (Röthlisberger, 1972). When inflow declines, the overburden pressure of the ice closes off the efficient channel system, returning it to an inefficient linked-cavity system (Kamb, 1987).

Because hydraulic efficiency affects subglacial water pressure and thus sliding, transitions between inefficient distributed systems and efficient channelized systems have been 
studied both by modeling and observations (e.g. Nienow and others, 1998; Flowers, 2015). Many studies focusing on subglacial conduit evolution have used dye tracing at land-terminating glaciers (e.g. Brugman, 1986; Nienow and others, 1998; Chandler and others, 2013). In these studies, dye is injected into moulins or streams at various locations on the glacier, and a dye detection device is installed downstream of the glacier terminus. Transit time is then calculated based on injection time and dye strength with time, and the hydraulic efficiency is inferred from multiple dyetracing surveys conducted throughout the melt season. Results from these studies have generally supported Kamb's (1987) hypothesis by showing evolution from inefficient drainage early in the melt season to more efficient drainage that propagates up-glacier as the melt season progresses. The ultimate endmember of inefficient drainage is subglacial storage of water, which was shown in a previous study by Rennermalm and others (2013).

Meltwater input sources available in Greenland include surface meltwater runoff via moulins and crevasses (diurnal, Catania and Neumann, 2010), rapid drainage of supraglacial lakes $(<1 \mathrm{~d}$, Boon and Sharp, 2003; Selmes and others, 2011; Morriss and others, 2013) and subglacial melt (Joughin and others, 2009). Supraglacial lake drainage events are important to the subglacial environment because they can temporarily exceed the capacity of the subglacial hydraulic system, and create enough hydraulic pressure to decouple the ice from the glacier bed locally (Das and others, 2008; Dow and others, 2015). This pulse of water temporarily increases ice velocity (Iken, 1981; Zwally and others, 2002; Das and others, 2008; Joughin and others, 2009; Doyle and others, 2013; Morriss and others, 2013). Because sustained high water flow results in transition to more efficient channelized systems, modeling indicates that an overall increase in the variability of water flow entering the system could drive faster ice motion (Schoof, 2010; Doyle and others, 2013), as the hydraulic system does not have time to adapt. Additionally, frictional heating at the bed of fast-flowing glaciers, such as Rink Isbræ, could produce melting at the base (e.g. Clarke, 2005; Van der Veen, 2007; Joughin and others, 2009). This contribution is likely negligible when compared with the meltwater runoff contribution in summer.

While it has been proposed that the seasonal cycle of a tidewater glacier's subglacial configuration could vary from that proposed by Kamb (1987) (e.g. Howat and others, 2010), few in situ measurements of a tidewater glacier's near-terminus hydraulic system exist (cf. fjord measurements: Walters and others, 1988; Motyka and others, 2003, 2013; Rignot and others, 2010). Vigorous calving activity and terminus instability prevent close access to the terminus, thwarting dye tracing. Additionally, fjords are much wider and deeper than proglacial rivers making it nearly impossible to successfully place instruments at discharge locations. Previous studies have successfully placed CTDs (conductivity, temperature, depth meters) and DCPs (acoustic Doppler current profilers) in the fjord for short periods of time and used heat and salt balance calculations to estimate water fluxes (Walters and others, 1988; Motyka and others, 2003, 2013; Rignot and others, 2010; Sutherland and Straneo, 2012; Chauché and others, 2014). At difficult to access tidewater glacier margins, reanalysed temperature combined with a runoff routing and retardation scheme is the most frequently used method to estimate runoff (e.g. Christoffersen and others, 2012; Sasgen and others, 2012; Xu and others, 2012, 2013; Moon and others, 2014; van As and others, 2014). Due to the challenges involved in making direct measurements of freshwater exiting the glacier terminus, we turn to the evidence provided by sediment-rich plumes.

\section{Sediment plumes}

After the onset of summer melt, meltwater percolates down through the snow, firn and ice on its way towards the bed. Meltwater that does not refreeze internally, refreeze at the bed, or remain in subglacial cavities, enters the subglacial drainage network, entrains sediment, and eventually exits the terminus of the glacier as a sediment-rich meltwater plume (Andrews and others, 1994). Once the sediment-rich freshwater enters the fjord at depth, buoyancy causes the plume to rise, entraining ambient ocean water and submarine meltwater. If the plume entrains enough ocean water, it can equilibrate and reach a neutral density below the surface, and never reach the surface (Jenkins, 1991; Straneo and others, 2011; Chauché and others, 2014). Thus, sediment-rich water introduced at depth is more likely to equilibrate before reaching the surface than sediment-free water, or sediment-rich water introduced at the surface (as in a land-terminating glacier). The depth of equilibration is dependent on the discharge rate, fjord stratification and circulation, fjord depth, and sediment concentration. Given all of the hydraulic controls on plume equilibration, surface sediment plume detection is a conservative measure of plume occurrence; there may be many more plumes than observed at the surface, and therefore our number is likely an underestimate.

Previous studies have quantified the area, center-line length and suspended sediment concentration (SSC) of the surface manifestation of sediment plumes around the Greenland coast through ground-based and satellite observations (Chu et al, 2009, 2012; Lund-Hansen and others, 2010; McGrath and others, 2010; Tedstone and Arnold, 2012). To generate a high-temporal-resolution time series, we choose only to determine the presence or absence of a plume. Plume visibility is dependent on sediment availability, water availability and sediment entrainment in the plume. For tidewater glaciers, the SSC exiting the glacier is dependent on the variability in subglacial hydraulic networks (Collins, 1990), their transitory nature (Alley and others, 1997), the episodic flushes of sediment (Stott and Grove, 2001) and the rate of bedrock erosion by the glacier (Hallet and others, 1996). To infer subglacial hydraulic efficiency, this study looks at the timing between meltwater input and sediment plumes.

\section{Study location}

Rink Isbræ $\left(71.70^{\circ} \mathrm{N}, 51.63^{\circ} \mathrm{W}\right)$ is located on the west coast of Greenland (Fig. 1) and has a $5.5 \mathrm{~km}$ wide terminus, calving into a $\sim 100 \mathrm{~km}$ long fjord. The fjord is filled with a thick mélange during the winter, which entirely breaks up early in the melt season. Previous research on Rink Isbræ shows that its terminus undergoes an annual cycle of advance and retreat $( \pm 0.5 \mathrm{~km})$, but is stable on interannual timescales, indicative of a grounded terminus with little to no ice tongue (Schild and Hamilton, 2013). Rink Isbræ is a fast-flowing glacier, moving at $\sim 14 \mathrm{~m} \mathrm{~d}^{-1}$ (Ahn and Box, 2010), and discharges $3.3 \%$ of the Greenland ice sheet's annual volume 


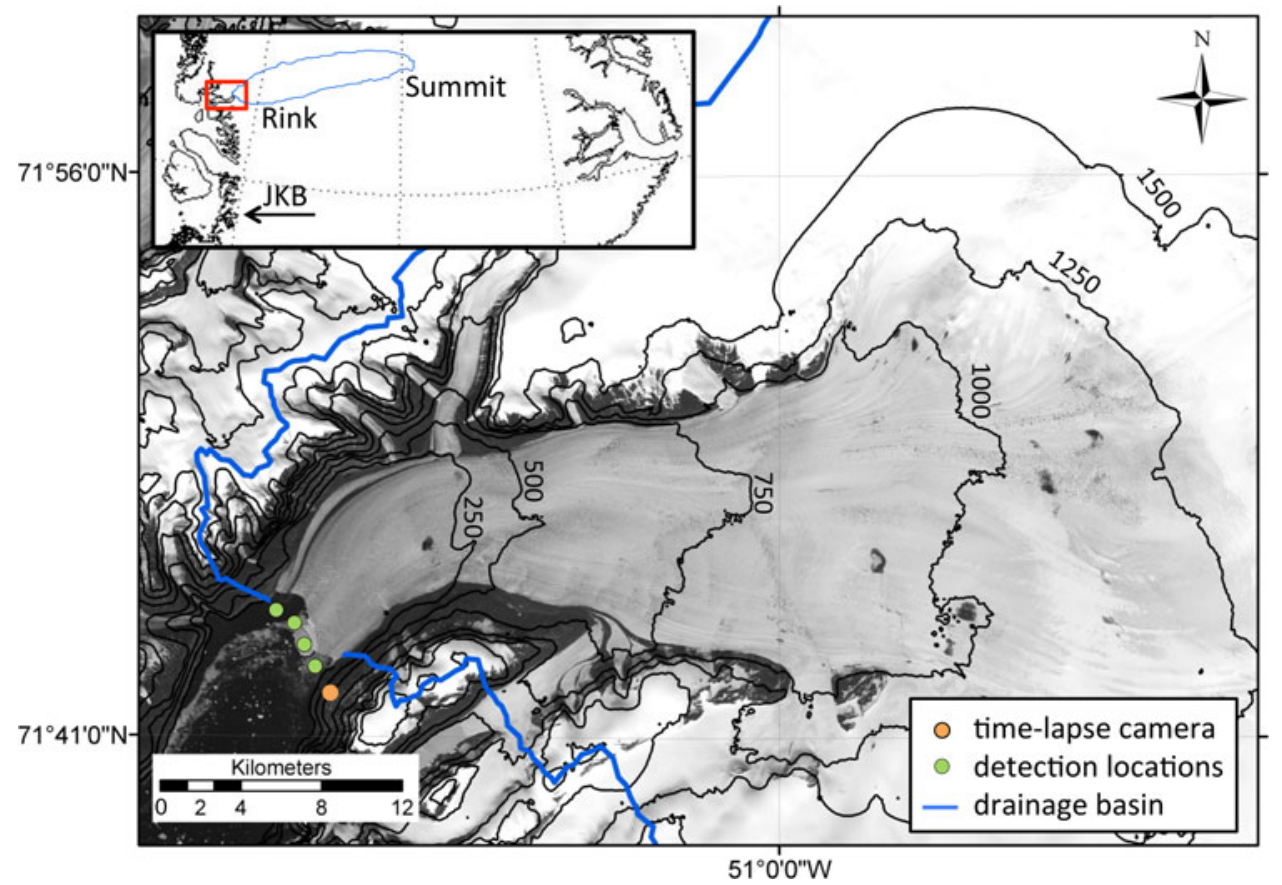

Fig. 1. Location map of Rink Isbræ (inset, red box) and Jakobshavn Isbræ identified for reference (JKB). The solid blue lines delineate the surface meltwater catchment basin, the black lines indicate elevation bands ( $m$ a.s.l., from GIMP DEM), the orange circle shows the location of the EIS time-lapse camera, and the green circles are the four fjord plume detection sites. The background image consists of three mosaicked ASTER images collected on 28 July 2001, 27 July 2004 and 12 June 2010.

loss through submarine melting and iceberg calving (Rignot and Kanagaratnam, 2006). The discharge consists mostly of moderately sized $\left(\sim 4.75 \mathrm{~km}^{2}\right)$ tabular icebergs (Schild and Hamilton, 2013), leaving the fjord predominantly ice free during the summer and early fall months (June-October).

\section{METHODS}

\section{Sediment plume detection}

\section{Overview}

To monitor plume emergence, we used a combination of satellite imagery and in situ time-lapse photography. Detecting a surface sediment plume using remotely sensed data relies on the sea surface near the terminus region being free of a thick ice mélange, and monitoring plume duration requires high temporal and high spatial resolutions. We used subdaily temporal resolution images from the Extreme Ice Survey (EIS) time-lapse cameras and the Moderate Resolution Imaging Spectroradiometer (MODIS) instrument on NASA's Aqua and Terra satellites. Because the limited field of view in the time-lapse imagery and the coarse spatial resolution $(250 \mathrm{~m})$ in the MODIS imagery make plume length or area measurement difficult, we focus on the simple presence or absence of the plume.

Both the MODIS instrument and time-lapse cameras are passive optical sensors relying on solar illumination, thereby restricting our time series to cloud-free, high-sunangle periods (minimizing shadows) from May to October each year, and overlap of the two detecting methods 2007-11. Sediment plume detection was limited by mélange break up in spring and low solar angle in the fall. We were also hindered by cases of very low-altitude cloud cover or recently calved icebergs, which obscured the view of fjord surface waters in both space-borne and ground-based images; however, these periods were generally $<2 \mathrm{~d}$. In these instances, we were not able to determine the presence or absence of a plume. We define plume presence as a detected plume in either MODIS or EIS time-lapse photography (Fig. 2).

\section{MODIS}

Previous studies have been successful in using MODIS band 1 (red, 0.62-0.67 $\mu \mathrm{m}, 250 \mathrm{~m}$ ) for quantifying SSC in runoff plumes, where a proglacial river from a land-terminating glacier drains into the sea (Chu and others, 2009, 2012; McGrath and others, 2010). Because Rink Isbræ is an actively calving tidewater glacier, individual MODIS pixels may contain both sediment plumes and icebergs in the fjord. In these instances, the spectral reflectance patterns of the individual components (water, ice, sediment plume) average together to create a mixed pixel reflectance. In these instances of mixed ice/clear water pixels, band 1 reflectance is the same as a sediment plume, thus preventing the use of a single band for plume detection in tidewater glacier settings.

To identify surface sediment plumes with MODIS, we used bands 1, 2 (near infrared (NIR); 0.84-0.87 $\mu \mathrm{m}, 250 \mathrm{~m}$ ) and band 3 (blue; 0.469-0.479 $\mu \mathrm{m}, 500 \mathrm{~m}$ ). While Chu and others (2012) developed an algorithm to eliminate ice pixels (using bands 1, 2, 3, 4 and 6), it is a very conservative method and, when used in this narrow fjord, would eliminate a sizeable number of our plume pixels. We therefore used pixel reflectance values in bands 1,2 and 3 at four detection locations across the terminus, to identify plumes. To identify surface plumes, we first used band 3 and set a high-reflectance threshold of $17 \%$, eliminating mixed pixels of ice and clear water (17-25\%) and ice and snow (>25\%), and set a low threshold of $10 \%$, eliminating open water $(<10 \%$, Fig. 3). The remaining pixels with reflectance between 10 


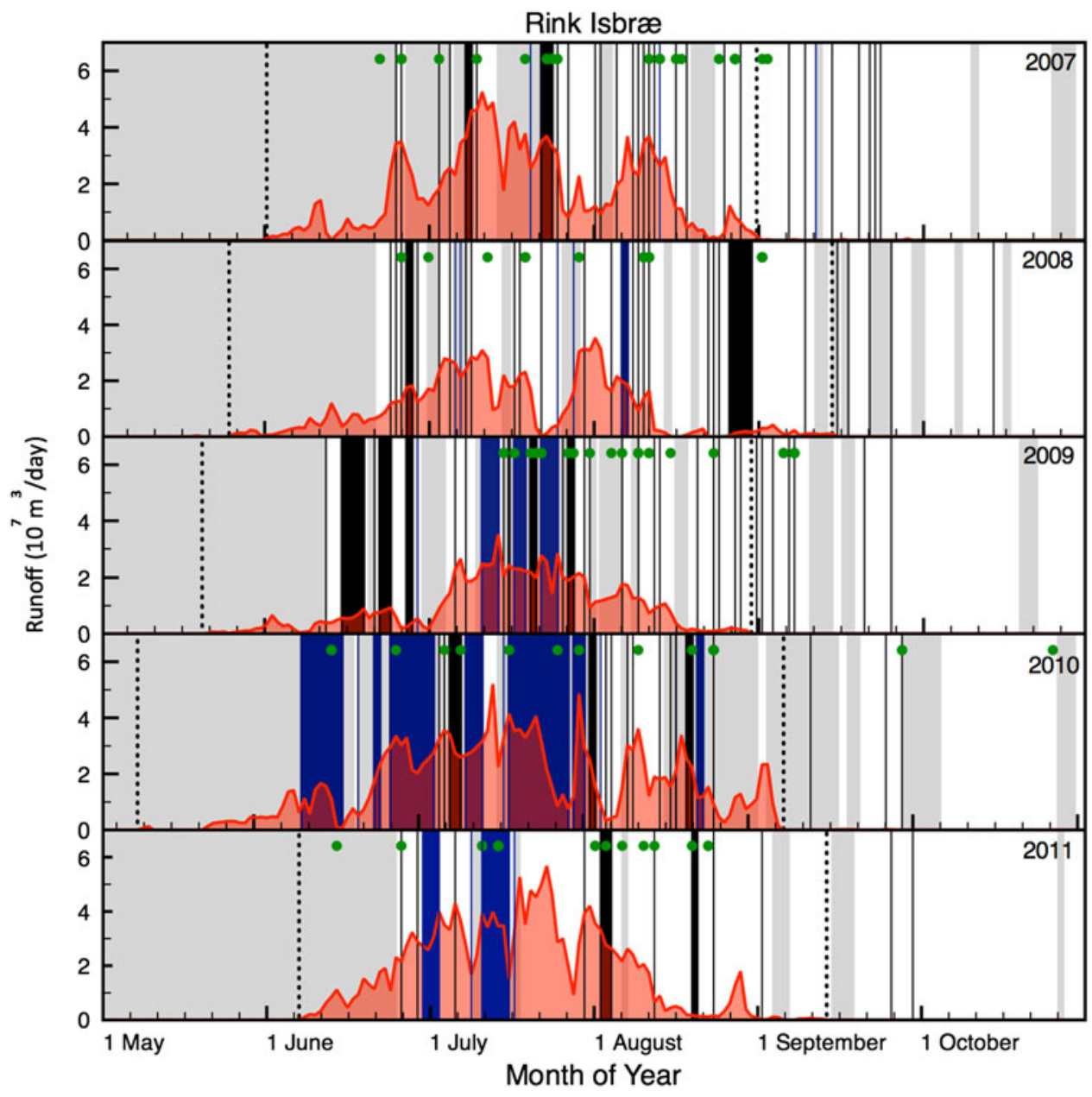

Fig. 2. Time series of meltwater runoff (red, $\mathrm{m}^{3} \mathrm{~d}^{-1}$ ) plotted against the presence of mélange (gray, detected with EIS imagery), sediment plume (black), ice plume (blue) or open water (white) in the fjord. The onset of melt is represented as a black-dashed vertical line and the occurrence of lake drainages is shown by green circles. While the runoff volume, behavior (bell curve vs bimodal distribution) and onset of melt vary between seasons, the duration of the melt season is fairly consistent (103 $\pm 10 \mathrm{~d})$. The duration of the surface expression of the plume also varies, ranging from $2 \mathrm{~h}$ to $17 \mathrm{~d}$.

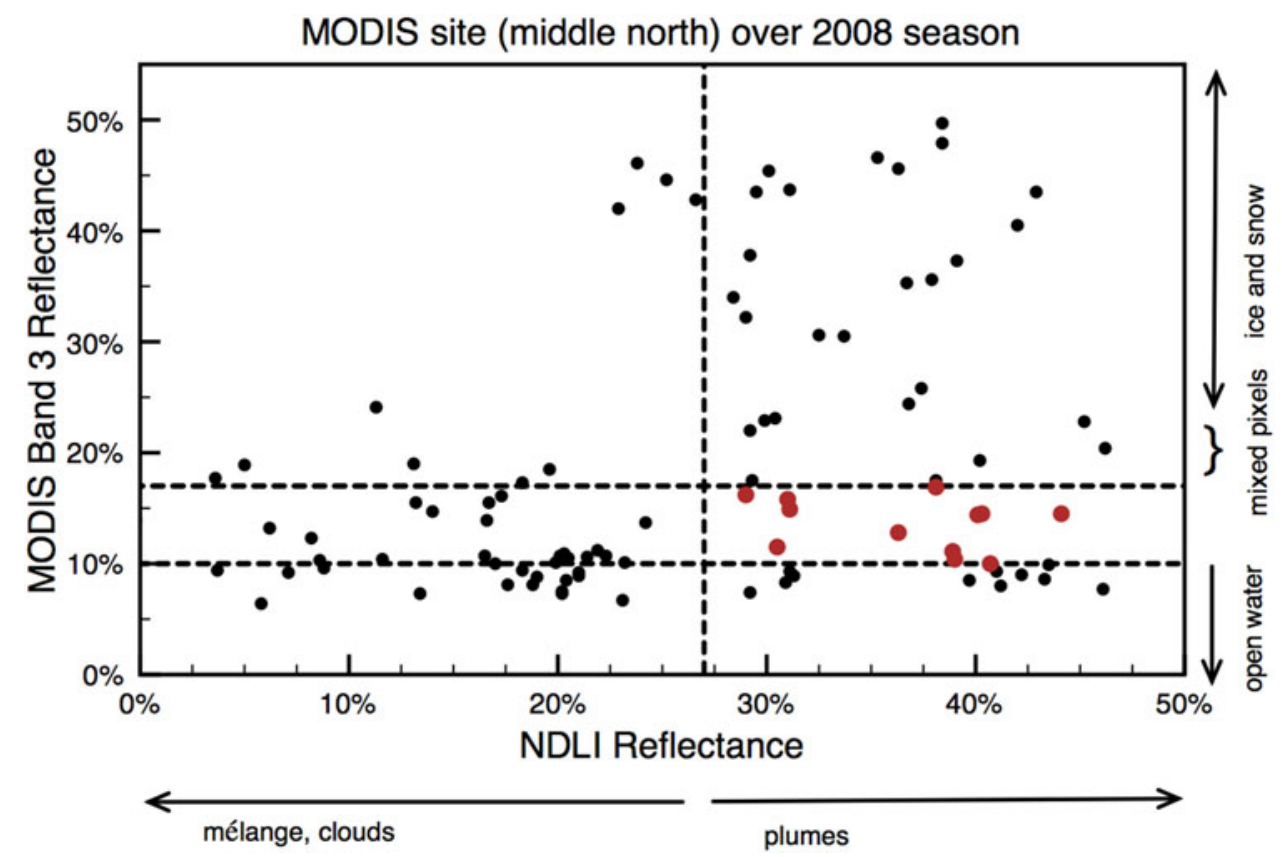

Fig. 3. A schematic representation shows the plume detection threshold in the MODIS band 3 (between 10 and $17 \%$ ) and NDLI (>27\%). The scatterplot values shown are from the middle north plume detection location over the 2008 season where the red dots are detected plumes. 
and $17 \%$ still included mixed pixels of mélange and open water, sediment plumes and clouds. We therefore applied another filter to eliminate everything besides a sediment plume. We used a ratio of bands 1 and 2 to differentiate ice from water. Water has a low reflectance (highly absorptive) in NIR, but is slightly more reflective in red, while ice has very similar high reflectance in both the bands. To exploit the differences in reflective properties between the two bands, and minimize the variable illumination and sensor geometry, we used the Normalized Difference Lake Index (NDLI, Morriss and others, 2013):

$$
\mathrm{NDLI}=\frac{R_{\mathrm{red}}-R_{\mathrm{NIR}}}{R_{\mathrm{red}}+R_{\mathrm{NIR}}}
$$

where $R$ is the reflectance and the subscript indicates the band's spectral region. This normalized index allowed us to distinguish sediment plumes in the water $(>27 \%)$ from the mixed mélange-open water pixels. Clouds are similar to ice in that they also have similar reflectance values in the red and NIR, and therefore can also be separated from sediment plumes using the NDLI value $(<27 \%)$. We interpreted any pixel that is between 10 and $17 \%$ reflectance in band 3 , and also $>27 \%$ in NDLI as a sediment plume (Fig. 3).

\section{Ground-based time-lapse photography}

In addition to the MODIS imagery we used time-lapse cameras. We validated our MODIS detection method by comparing onset times of sediment plumes identified in our MODIS imagery with sediment plumes identified visually (sediment-rich water against clear water, Fig. 4a) in timelapse photography of Rink Isbræ acquired every 30 min by EIS from May 2007 to July 2011. While plume detection
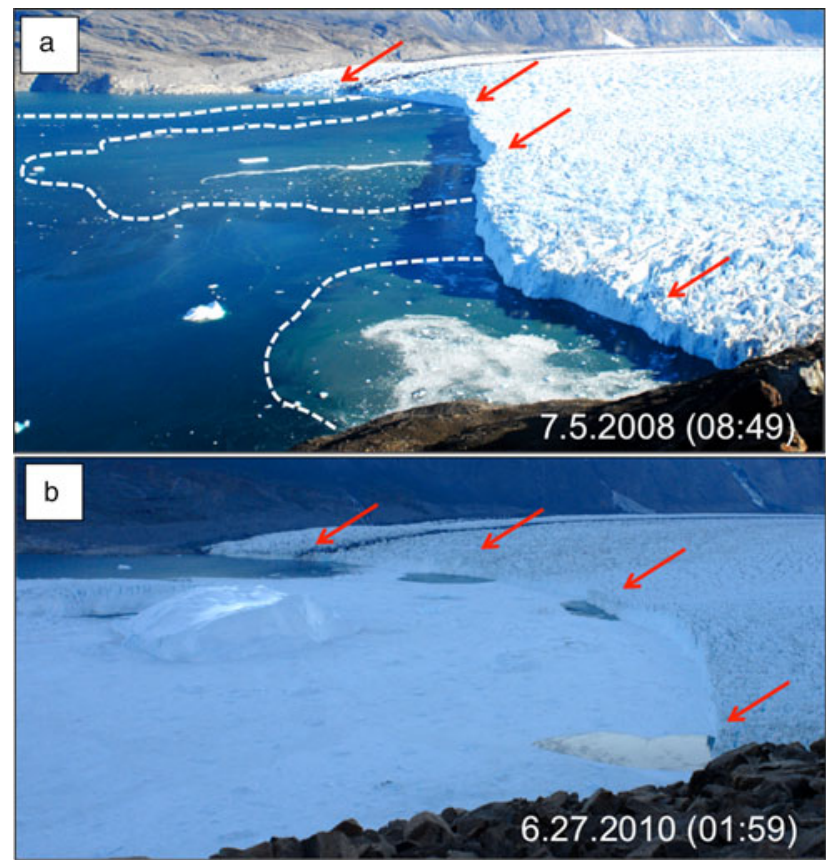

Fig. 4. Ground-based EIS time-lapse photographs where the arrows identify four EIS-determined exit locations, corresponding to MODIS detection locations, for open water sediment plumes (a) and ice plumes (b). in the time-lapse photography is affected by fjord surface roughness and glare, the time-lapse photography enables plume identification in instances where sediment plumes are too small to be detected by MODIS. These include instances where plumes break through the disintegrating mélange and bergy bits at the terminus (Fig. 4b). Because such plumes are undetectable by MODIS and are surrounded by ice, we cannot confirm the presence of sediment either through spectral reflectance profiles or comparison against open ocean water. While we do hypothesize that these plumes are subglacial in origin, we cannot be certain they contain sediment and will call them ice plumes (Fig. 4b, blue lines in Fig. 2).

\section{Lake drainage}

To assess the relationship between plume appearance and supraglacial lake drainage over our study period (2007$11)$, we constructed a sub-daily time series of supraglacial lake evolution and lake drainage for the Rink Isbræ drainage basin using MODIS imagery. We again used NDLI to determine the presence of water (NDLI $>21 \%$ ) at 33 manually digitized lake locations. We identified lake drainage as the date and time of the last image prior to the onset of draining (green circles in Fig. 2). Lakes with an area smaller than four pixels $\left(<250000 \mathrm{~m}^{2}\right)$ are difficult to resolve in $250 \mathrm{~m}$ MODIS imagery and were not included in the lake drainage time series. Had we chosen a higher spatial resolution dataset (e.g. ASTER or Landsat), we could have resolved these smaller lakes, but would not have had the temporal resolution to identify their drainage times. Additionally, lakes that did not drain during the summer and iced over in the fall were difficult to classify at MODIS resolution, causing the lakes to appear to have drained, when they had not. In all instances, we were able to use higher resolution imagery (ASTER and Landsat 7, ETM+) to differentiate icecovered lakes from drained lakes.

\section{Surface melt}

We used the $90 \mathrm{~m}$ resolution GIMP DEM of Greenland (Howat and others, 2014) to delineate the surface hydrology boundaries of Rink basin (Fig. 1). To estimate surface melting within the basin, we used the daily average runoff output from the Regional Atmospheric Climate Model (RACMO version 2.3; e.g. Van Meijgaard and others, 2008; Sasgen and others, 2012; van As and others, 2014). Modeled daily average runoff is identified as the amount of liquid water flux (composed of meltwater and rain) at any given location on the surface of the ice sheet that is available to drain to the glacier bed, accounting for percolation and refreezing in the snow (Moon and others, 2014; Van Meijgaard and others, 2008). To calculate a daily runoff amount from the RACMO output given in $\mathrm{kg} \mathrm{m}^{-2} \mathrm{~s}^{-1}$ in each grid cell, we multiplied the pixel runoff by the pixel area $\left(\sim 123.7 \mathrm{~km}^{2}\right)$, converted the measurement into $\mathrm{m}^{3} \mathrm{~d}^{-1}$, and summed all the pixels (red curve in Fig. 2) whose center falls within the catchment basin delineation. We defined the start of the runoff season as the first day when the runoff was more than two standard deviations (SD) above the average winter time (DJF) runoff, and defined the end of the runoff season as the last day before the runoff fell below the two SD threshold (dashed lines in Fig. 2). 


\section{RESULTS}

\section{Sediment plumes}

In total, we detected 136 plumes with MODIS and EIS timelapse cameras. Of the detected plumes, there was a $22 \%$ overlap between MODIS and EIS plume detection, where MODIS successfully identified $56 \%$ and EIS detected $66 \%$ of the total detected plumes. Discrepancies in the appearance of a plume between the MODIS satellite imagery and EIS time-lapse photography are due largely to differences in both spatial and temporal resolution and viewing geometry relative to the terminus. Low spatial resolution, shadows in the fjord due to surrounding topography, and high cloud cover over the terminus accounted for the missed plumes using MODIS imagery. Specular reflection on the fjord surface due to the angle of the EIS time-lapse camera relative to the water and a cessation of image collection before the completion of the 2011 season led to missed plumes in the EIS imagery.

The first detected plume of each season was as early as day 159 (June 8, 2010) and as late as day 178 (June 27, 2011), with the average plume season (length of time between the first and last plume) lasting $102 \pm 8 \mathrm{~d}$ (Table 1). We detected sediment plumes almost immediately upon the mélange break up, and in 2 years (2007 and 2010) ice plumes were observed (through EIS time-lapse camera detection, open water and ice at the terminus, e.g. Fig. 4b) before the mélange had fully dispersed. Our method detected an average of $27 \pm 6$ surface plumes per season lasting from $2.5 \mathrm{~h}$ to $17 \mathrm{~d}$. The high temporal resolution of our time-lapse imagery allowed us to observe the short duration of these plumes, which was not possible in previous studies (e.g. Chauché and others, 2014).

The size, shape and number of plumes present at the surface varied throughout the study period. Through the time-lapse imagery, we identified four distinct locations of plume emergence at the terminus (four detection locations in Figs 1 and 4). These locations were identified as the most prevalent areas of sediment plume appearance after in-depth analysis of the EIS time-lapse imagery. In one instance during our study period (2007-11), all four locations were active at the same time (Fig. 4b); however, in most instances, the two center plume locations appeared to combine and create one large plume (Fig. 4a). During instances of plume appearance through mélange cover, plumes were small in area $\left(<125000 \mathrm{~m}^{2}\right.$ or two $250 \mathrm{~m}$ pixels), and EIS imagery showed a semicircular opening in the ice against the terminus. The location of the semicircle remained constant, suggesting channelized drainage, but the diameter would change between each acquisition of time-lapse imagery (30 min), suggesting active subglacial water discharge as opposed to stagnant surface water. During instances of plume appearance in open water, the plumes were typically elongated in shape with the long axis oriented perpendicular to the terminus and moving down fjord. In instances when multiple plume exit locations were active concurrently in open water, plumes appeared to mix with one another at the terminus (Fig. 4a).

\section{Melt record}

Between 2007 and 2011 there was variability in onset of surface runoff and surface runoff volume (cumulative runoff), while the duration of the runoff season was fairly consistent $(103 \pm 10 \mathrm{~d}$, Table 1$)$. The summer of 2009 had the lowest cumulative runoff $\left(0.966 \times 10^{9} \mathrm{~m}^{3}\right.$, Table 1$)$, but was consistent with the number of plumes in 2008 (Table 1). There was significantly less cumulative runoff in the 2008 and 2009 seasons compared with the 2007, 2010 and 2011 summer seasons. These three seasons showed much larger cumulative runoff values $\left(1.609 \times 10^{9} \mathrm{~m}^{3}\right.$, $1.895 \times 10^{9} \mathrm{~m}^{3}$ and $1.756 \times 10^{9} \mathrm{~m}^{3}$, respectively, Table 1); however, the number of individual plumes in 2007, 2010 and 2011 was fewer than in 2008 and 2009 (31, 21, 18 vs 33,33 , respectively). The timing of maximum runoff varied between day 193 (12 July 2007) and day 214 (1 August 2008). The runoff curve took one of two forms: a normal distribution $(2009,2011)$ or a bimodal distribution (2007, $2008,2010)$. Daily seasonal runoff maximas ranged from $3.51 \times 10^{7} \mathrm{~m}^{3} \mathrm{~d}^{-1}$ (15 July, 2009) to $5.67 \times 10^{7} \mathrm{~m}^{3} \mathrm{~d}^{-1}$ (24 July 2011), although there is again a marked difference between 2008 and 2009 (maximas $\sim 3.5 \times 10^{7} \mathrm{~m}^{3} \mathrm{~d}^{-1}$ ) and 2007, 2010 and 2011 (maximas $>5 \times 10^{7} \mathrm{~m}^{3} \mathrm{~d}^{-1}$ ).

\section{Timing of melt and plumes}

There was an average of $24 \pm 4 \mathrm{~d}$ between the melt onset and the observation of a sediment plume. However, due to the presence of ice mélange and the potential for subsurface plumes, comparisons between melt onset and plume appearance only represents observable sediment plumes, and not necessarily the first subglacial discharge of meltwater to the fjord.

In every year of this study (2007-11), the occurrence of sediment plumes continued through the duration of the surface runoff season and after the termination of the surface runoff season $(23 \pm 5 \mathrm{~d}$, Table 1$)$. It is important to point out that the low number of observed plume events after the cessation of runoff in 2011 is likely due to missing data. A majority of the late season plumes are smaller in size and occur within the shadow of the surrounding mountains. Subsequently, the late season plumes are more readily identified through the EIS time-lapse imagery than MODIS imagery. The EIS time-lapse cameras were removed on July 22, 2011 (day 203) and therefore it is probable that the lack of late season plumes in 2011 results from our sampling method relying on time-lapse cameras for detection, rather than the scarcity of plumes.

\section{DISCUSSION}

\section{Episodic plume events}

In Rink fjord, we propose that subglacial freshwater sediment plumes entrain ambient ocean water as they move toward the surface, and that each observed plume is the result of temporal variability in discharge. The same intermittent surface plume record could also result from a persistent flow of meltwater (as at land-terminating glaciers in the summer) if time-varying stratification of fjord waters periodically prevented the plume from reaching the surface (e.g. Straneo and others, 2011, 2012). We did not have any means to measure fjord hydrography or its variability, so we cannot reject the possibility of variable stratification as a control on plume appearance. Rather we note that it is unlikely for fjord stratification to change sufficiently over a period of hours, but more likely that the stratification does evolve over a summer melt season (Straneo and others, 
Table 1. The onset of runoff, first plume, mélange opening, end of runoff and last plume (rows 1, 2, 4, 6 and 7 , respectively) are shown in day of year (doy) for the 5 years of our study. The timing between the start of runoff and the first plume, the mélange opening and the first plume, the last plume and the end of runoff, the plume season duration and the runoff season duration (rows 3, 5, 7, 8, 9 and 13, respectively) are represented in number of days. The number of individual plumes (row 10) and the total duration of plumes (row 11) are given as integers. The cumulative runoff for each year (row 12) is shown in $\mathrm{m}^{3}$

\begin{tabular}{|c|c|c|c|c|c|c|}
\hline Row & 2007 & 2008 & 2009 & 2010 & 2011 & $\mathrm{Avg} \pm \mathrm{SD}$ \\
\hline 1 Runoff onset (doy) & 153 & 147 & 142 & 131 & 160 & 147 \\
\hline 2 First plume (doy) & 177 & 176 & 164 & 159 & 178 & 171 \\
\hline 3 Runoff $\rightarrow$ first plume (days) & 24 & 29 & 22 & 29 & 18 & $24 \pm 4$ \\
\hline 4 Mélange opens (doy) & 187 & 173 & 164 & 169 & 177 & 174 \\
\hline 5 Mélange $\rightarrow$ first plume (days) & -10 & 3 & 0 & -10 & 1 & -3 \\
\hline 6 End of runoff (doy) & 244 & 257 & 242 & 248 & 256 & 249 \\
\hline 7 Last plume (doy) & 267 & 288 & 269 & 268 & 273 & 273 \\
\hline 8 End of runoff (days) $\rightarrow$ last plume & 23 & 30 & 27 & 20 & 17 & $23 \pm 5$ \\
\hline 9 Total plume season (days) & 90 & 111 & 105 & 108 & 95 & $102 \pm 8$ \\
\hline 10 Number of plumes & 31 & 33 & 33 & 21 & 18 & $27 \pm 6$ \\
\hline 11 Number of plume days & 34 & 39 & 52 & 63 & 28 & 43.2 \\
\hline 12 Cumulative runoff $\left(10^{9} \mathrm{~m}^{3}\right)$ & 1.609 & 1.061 & 0.966 & 1.895 & 1.756 & 1.457 \\
\hline 13 Total runoff days & 91 & 111 & 100 & 118 & 96 & $103 \pm 10$ \\
\hline
\end{tabular}

2011, 2012). Therefore, the fjord stratification likely does not control the duration of plumes at shorter than weekly timescales, but their appearance at the surface on a seasonal timescale.

The frequency of sediment plumes, in combination with the lack of temporal correlation between lake drainages and plume occurrence, indicates that lake drainages are not the primary driver of sediment plumes and that multiple pathways exist from the surface of the ice sheet to the subglacial system. The RACMO runoff product does not account for the subglacial configuration in the runoff calculation, only the quantity of meltwater potentially entering the subglacial system at a given surface location. While some surface runoff peaks correspond nicely to plume events, we again see more plumes than meltwater runoff peaks. We suggest this discrepancy between input and output likely results from the subglacial hydrology configuration.

The creation of a channelized system relies on flowing water to enlarge existing pathways faster than the overburden pressure can close them. The rapid motion of a tidewater glacier could overwhelm this process, continually destroying the nascent tunnel system faster than it can grow. Simultaneously this fast motion would also enable new cavities and passageways to form, leaving the subglacial network of a tidewater glacier in a persistent state of inefficient drainage. If the subglacial configuration were to transition from an inefficient linked-cavity configuration to an efficient channelized configuration, we would expect to see a slowdown in surface velocity when the subglacial network evolved to accommodate the water moving through it (cf. Bartholomaus and others, 2008; Howat and others, 2010; Schoof, 2010; Sundal and others, 2011). However, Howat and others (2010) observed that Rink Isbræ does not have a summer time slowdown event (also corroborated by Moon and others, 2014) indicative of the transition between inefficient and efficient drainage, while other slower moving tidewater glaciers in the West Greenland region did experience a mid-summer decrease in surface velocity. Howat and others (2010) hypothesized a persistent inefficient drainage to explain velocity anomalies between slow- and fast-moving tidewater glaciers. Limited channel development could also explain why we see no consistent relationship between peaks in meltwater input to the subglacial system, and plume appearance.

While the lack of a mid-summer slowdown in surface velocity (Howat and others, 2010; Moon and others, 2014), and the lack of relationship between meltwater input and plume appearance support the hypothesis of Rink Isbræ having a persistent inefficient drainage network, the presence of four consistent interannual exit locations indicate some form of channelized network is in place. This could be explained by a set of bedrock channels (N-channels, Nye, 1969) rather than the ice channels (R-channels, Röthlisberger, 1972) which would result from an efficient subglacial configuration.

\section{Submarine melt}

The proposed persistent inefficient subglacial configuration, as well as the observed multi-year exit locations (likely due to bedrock channels), has implications for modeling and understanding submarine melting. As subglacial water enters the fjord at depth, the plume drives convective motion and entrains warm ocean water. As the plume buoyantly moves toward the surface, the entrained warm ocean is brought into contact with the terminus, increasing the melting rate of the terminus and modifying the terminus geometry (Jenkins, 2011; Xu and others, 2012; Motyka and others, 2013; Sciascia and others, 2013). Through this process, subglacial freshwater discharge has a large impact on the spatial extent, quantity and rate of submarine melting at tidewater glaciers. The configuration of the subglacial network determines the amount of freshwater exiting and ultimately how much of the glacier terminus will experience enhanced submarine melting (Kimura and others, 2014). Recent modeling work has furthered our understanding of this process, showing that an increase in the number of discrete plumes across the width of a terminus can have a greater impact on submarine melting due to the entrainment of larger volumes of ocean water (Cenedese and Linden, 2014; Slater and others, 2015). Additionally, submarine melting modifies the geometry of the terminus face potentially creating an unstable terminus shape where calving is more likely. In these instances, submarine melting and plume exit 
locations could also impact calving location and frequency. In combining this record of plume appearance with a detailed record of calving location and style (an extension of Schild and Hamilton, 2013), we can continue exploring this relationship between subglacial discharge and calving rate with in situ data.

\section{Mélange stability}

Many field and modeling studies have previously shown the importance of mélange presence on terminus stability. In an in-depth study of Jakobshavn Isbræ, Amundson and others (2010) found that the strengthening of the mélange with the addition of sea ice helped to stabilize calving and support a winter-time advance of the terminus. Upon retreat of the sea-ice margins in the spring, the mélange relaxes and calving is rejuvenated. Vieli and Nick (2011) modeled this ice/ocean interface and showed that enhanced ocean melt could trigger the dynamic changes observed at Jakobshavn Isbræ, but it heavily relied on the loss of ice buttressing. In this study, we observed the appearance of ice plumes breaking through the wintertime mélange (e.g. 2010, Fig. 4b). This is evidence at a local scale of meltwater impacting mélange behavior, with potentially larger implications of meltwater reducing mélange stability, and initiating mélange disintegration.

\section{Subglacial storage}

The appearance of sediment plumes well after the cessation of runoff ( $23 \pm 5 \mathrm{~d}$, Table 1 ) is indicative of the presence of an inefficient subglacial configuration (e.g. linked cavity, Kamb, 1987) and supports the idea of subglacial water storage (Colgan and others, 2011; Motyka and others, 2013; Rennermalm and others, 2013). To determine the most likely scenario, we calculated the transit time of water to the terminus on the last day of the runoff season. We first set our input location as the farthest pixel from the terminus that experienced melt, and determined the along-flow distance from our input location to the terminus. We then calculated the transit time based on an inefficient subglacial flow velocity of $0.25 \mathrm{~m} \mathrm{~s}^{-1}$, determined at a Greenland land-terminating glacier (Chandler and others, 2013) for each year in our study. This process resulted in transit times between $7.5 \mathrm{~h}$ and $2.6 \mathrm{~d}$, an order of magnitude shorter than the time between the cessation of runoff and the last observed plume, $23 \pm 5 \mathrm{~d}$ (Table 1). The lengthy transit time likely results from a combination of an inefficient drainage network and the presence of subglacial storage cavities (also suggested by Cowton and others, 2013 for a land-terminating glacier). It is again important to point out that the time-lapse cameras were removed on July 22, 2011 (day 203) and therefore the absence of late season plumes in 2011 is likely the result of our sampling method, so we used only the four previous years (2007-10) in late season analysis.

The summer of 2010 experienced the largest amount of runoff in our time series $\left(1.895 \times 10^{9} \mathrm{~m}^{3}\right.$, Table 1$)$ and also the highest number of plume days (the number of days plumes were visible on the surface, $63 \mathrm{~d}$, Table 1). This is what we would expect: the higher the cumulative runoff, the greater the number of plume days; however, the years with the lowest and second lowest number of plume days (2011 and 2007, respectively) had the second and third highest cumulative runoff numbers. Again, 2011 is likely missing a few end of season plumes due to sampling, but the expected relationship of high runoff and a high number of plume days does not persist. Apart from the possible impact of variable fjord circulation or stratification, these findings imply a complex relationship between melt and discharge that likely includes subglacial storage.

\section{CONCLUSIONS}

We investigated the subglacial hydrology of Rink Isbræ, a fast-flowing West Greenland tidewater glacier, using hightemporal-resolution satellite imagery, time-lapse photography, and modeled runoff estimates. We found that sediment plumes appear episodically at four distinct locations across the terminus, and their timing in relation to meltwater availability implicates the presence of subglacial storage. The lack of either a seasonal velocity change or a correspondence between meltwater availability and plume occurrence suggests that the subglacial system persists in a state of inefficient drainage. Although the inaccessibility of the subglacial environment prohibits direct hydraulic observations, we successfully identified the timing and duration of surface sediment plumes in the fjord of a tidewater glacier and examined the relationship between surface runoff, lake drainages and sediment plumes.

We observed episodic plume emergence lasting hours to days beginning just before the winter mélange disintegration and continuing beyond the meltwater runoff season. The appearance of plumes breaking through the weakened wintertime mélange suggests that subglacial meltwater may influence the stability of a mélange at the tidewater glacier terminus. The appearance of plumes after the cessation of melt suggests subglacial storage, possibly in combination with an inefficient drainage configuration.

The episodic nature of the plume events suggests temporal variability in discharge that is independent of the diurnal cycle; however, the role that fjord stratification plays in plume appearance remains uncertain. We observed four distinct exit locations. High velocity may also inhibit the establishment of a channelized subglacial network, and an inefficient system, such as a linked-cavity configuration, may persist throughout the runoff season. With this configuration, water beneath Rink Isbræ would not be immediately released but instead be stored within a shifting linked-cavity system and released episodically where it would then flow into one of the four bedrock channels near the terminus. The storage of meltwater in a linked-cavity system explains why we see no relationship between supraglacial lake drainages, surface runoff peaks, and proglacial discharge, as would be expected in an efficient subglacial configuration. This hypothesized contrast in subglacial hydrology configuration and observed contrast in plume behavior highlights the need for specific tidewater glacier hydrology studies and the importance of fjord stratification data. By understanding the efficiency of the subglacial drainage system and its storage capacity, we can better constrain the influence of meltwater input on ice velocities, frontal ablation and, ultimately, icesheet mass balance.

\section{ACKNOWLEDGEMENTS}

We would like to thank the US National Science foundation for their support (IGERT Award 0801490, GK-12 Award 
0947790), M.R. van den Broeke for his assistance in staging and processing the RACMO dataset, the Extreme Ice Survey for the use of their time-lapse imagery and Matthew Kennedy for staging the imagery. We would also like to thank the reviewers for their very helpful and insightful comments and suggestions.

\section{REFERENCES}

Ahn, Y and Box, JE (2010) Glacier velocities from time-lapse photos: technique development and first results from the Extreme Ice Survey (EIS) in Greenland. J. Glaciol., 56, 198 (doi: 10.3189/ 002214310793146313)

Alley, RB and 5 others (1997) How glaciers entrain and transport basal sediment: physical constraints. Quat. Sci. Rev., 16(9), 1017-1038 (doi: 10.1016/S0277-3791(97)00034-6)

Amundson, JA and 5 others (2010) Ice mélange dynamics and implications for terminus stability, Jakobshavn Isbræ, Greenland. J. Geophys. Res., 115(F01005) (doi: 10.1029/2009JF001405)

Andersen, ML and 5 others (2011) Quantitative estimates of velocity sensitivity to surface melt variations at a large Greenland outlet glacier. J. Glaciol., 57(204) (doi: 10.3189/002214311797409785)

Andrews, JT, Milliman, JD, Jennings, AE, Rynes, N and Dwyer, J (1994) Sediment thickness and Holocene glacial marine sedimentation-rates in 3 East Greenland fjords (ca. $\left.68^{\circ} \mathrm{N}\right)$. J. Geol., 102, 669-683

Bamber, JL, van den Broeke, M, Ettema, J, Lenaerts, J and Rignot, E (2012) Recent large increases in freshwater fluxes from Greenland into the North Atlantic. Geophys. Res. Lett., 39(19) (doi: 10.1029/2012GL052552)

Bartholomaus, TC, Anderson, RS and Anderson, SP (2008) Response of glacier basal motion to transient water storage. Nat. Geosci., 1, 33-37 (doi: 10.1038/ngeo.2007.52)

Benn, DI and Evans, DJA (2010) Glaciers and glaciation. Routledge, London, UK.

Boon, S and Sharp, M (2003) The role of hydrologically-driven ice fracture in drainage system evolution on an Arctic glacier. Geophys. Res. Lett., 30(18) (doi: 10.1029/2003GL018934)

Brugman, MM (1986) Waterflow at the base of a surging glacier (PhD thesis, California Institute of Technology, Pasadena, California)

Catania, GA and Neumann, TA (2010) Persistent englacial drainage features in the Greenland ice sheet. Geophys. Res. Lett., 37(2) (doi: 10.1029/2009GL041108)

Cenedese, C and Linden, PF (2014) Entrainment in two coalescing axisymmetric turbulent plumes. J. Fluid Mech., 752 (doi: 10.1017/jfm.2014.389)

Chandler, DM and 11 others (2013) Evolution of the subglacial drainage system beneath the Greenland ice sheet revealed by tracers. Nat. Geosci., 6, 195-198 (doi: 10.1038/ngeo1737)

Chauché, N and 8 others (2014) Ice-ocean interaction and calving front morphology at two west Greenland tidewater outlet glaciers. Cryosphere, 8, 1457-1468 (doi: 10.5194/tc-8-1457-2014)

Christoffersen, $\mathrm{P}$, O'Leary, $\mathrm{M}$, van Angelen, $\mathrm{JH}$ and van den Broeke, M (2012) Partitioning effects from ocean and atmosphere on the calving stability of Kangerdlugssuaq Glacier, East Greenland. Ann. Glaciol., 53(60) (doi: 10.3189/2012 AoG60A087)

Chu, VW and 5 others (2009) Sediment plume response to surface melting and supraglacial lake drainages on the Greenland ice sheet. J. Glaciol., 55(194), 1072-1082 (doi: 10.3189/ 002214309790794904)

Chu, VW, Smith, LC, Rennermalm, AK, Forster, RR and Box, JE (2012) Hydrologic controls on coastal suspended sediment plumes around the Greenland ice sheet. Cryosphere, 6, 1-19 (doi: 10.5194/tc-6-1-2012)

Clarke, GKC (2005) Subglacial processes. Annu. Rev. Earth Planet. Sci., 33, 247-276 (doi: 10.1146/annurev.earth.33.092203.122621)
Colgan, W and 7 others (2011) An increase in crevasse extent, West Greenland: hydrologic implications. Gephys. Res. Lett., 38(18) (doi: 10.1029/2011GL048491)

Collins, DN (1990) Seasonal and annual variations of suspended sediment transport in meltwaters draining from an Alpine glacier. IAHS Publ, 193, 439-446

Cowton, T and 7 others (2013) Evolution of drainage system morphology at a land-terminating Greenlandic outlet glacier. J. Geophys. Res., 118, 29-41 (doi: 10.1029/2012JF002540)

Cowton, T, Slater, D, Sole, A, Goldberg, D and Nienow, P (2015) Modeling the impact of glacial runoff on fjord circulation and submarine melt rate using a new subgrid-scale parameterization for glacial plumes. J. Geophys. Res., 120, 796-812 (doi: 10. 1002/2014JC010324)

Das, SB and 6 others (2008) Fracture propagation to the base of the Greenland ice sheet during supraglacial lake drainage. Science, 320, 778-781 (doi: 10.1126/science.1153360)

Dow, CF and 10 others (2015) Modeling of subglacial hydrological development following rapid supraglacial lake drainage. J. Geophys. Res., 120, 1127-1147 (doi: 10.1002/2014JF003333)

Doyle, SH and 9 others (2013) Ice tectonic deformation during the rapid in situ drainage of a supraglacial lake on the Greenland ice sheet. Cryosphere, 7, 129-140 (doi: 10.5194/tc-7-129-2013)

Ewert, $\mathrm{H}$ and Dietrich, AGR (2012) Volume and mass changes of the Greenland ice sheet inferred from ICESat and GRACE. J. Geodynam., 59-60, 111-123 (doi: 10.1016/j.jog.2011.06.003)

Flowers, GE (2015) Modelling water flow under glaciers and ice sheets. Proc. R. Soc. Lond. A, 471, 2176 (doi: 10.1098/ vspa.2014.0907)

Hallet, B, Hunter, L and Bogen, J (1996) Rates of erosion and sediment evacuation by glaciers: a review of field data and their implications. Glob. Planet. Change, 12(1-4), 213-235 (doi: 10.1016/0921-8181(95)00021-6)

Howat, I, Box, JE, Ahn, Y, Herrington, A and McFadden, EM (2010) Seasonal variability in the dynamics of marine-terminating outlet glaciers in Greenland. J. Glaciol., 56, 601-613 (doi: 10.3189/ 002214310793146232)

Howat, IM, Negrete, A and Smith, BE (2014) The Greenland Ice Mapping Project (GIMP) land classification and surface elevation data sets. Cryosphere, 8, 1509-1518 (doi: 10.5194/tc-8-1509-2014)

Iken, A (1981) The effect of the subglacial water pressure on the sliding velocity of a glacier in an idealized numerical model. J. Glaciol., 27(97)

Jenkins, A (1991) A one-dimensional model of ice shelf-ocean interaction. J. Geophys. Res., 96(C11), 20671-20677 (doi: 10.1029/ 91JC01842)

Jenkins, A (2011) Convection-driven melting near the grounding lines of ice shelves and tidewater glaciers. Am. Meteorol. Soc., 41(2), 2279-2294 (doi: 10.1175/JPO-D-11-03.1)

Joughin, I and 6 others (2009) Basal conditions for Pine Island and Thwaites Glaciers, West Antarctica, determined using satellite and airborne data. J. Glaciol., 55(190), 245-257 (doi: 10.3189/ 002214309788608705)

Kamb, B (1987) Glacier surge mechanism based on linked cavity configuration of the basal water conduit system. J. Geophys. Res., 92(B9), 9083-9100 (doi: 10.1029/JB092iB09p09083)

Kimura, S, Holland, PR and Jenkins, A (2014) The effect of meltwater plumes on the melting of a vertical glacier face. Am. Meteorol. Soc., 44(12), 3099-3117 (doi: 10.1175/JPO-D-13-0219.1)

Lund-Hansen, LC, Andersen, TJ, Nielsen, MH and Pejrup, M (2010) Suspended matter, Chl-a, CDOM, Grain sizes, and optical properties in the Arctic fjord-type estuary, Kangerlussuaq, West Greenland during summer. Estuar. Coasts, 33(6), 1442-1451 (doi: 10.1007/s12237-010-9300-7)

McGrath, D and 5 others (2010) Sediment plumes as a proxy for local ice-sheet runoff in Kangerlussuaq fjord, West Greenland. J. Glaciol., 56(199), 813-821 (doi: 10.3189/002214310794457227)

Moon, T and 6 others (2014) Distinct patterns of seasonal Greenland glacier velocity. Geophys. Res. Lett., 41, 7209-7216 (doi: 10.1002/2014GL061836) 
Morriss, BF and 7 others (2013) A ten-year record of supraglacial lake evolution and rapid drainage in West Greenland using an automated processing algorithm for multispectral imagery. Cryosphere, 7, 1869-1877 (doi: 10.5194/tcd-7-1869-2013)

Motyka, RJ, Hunter, L, Echelmeyer, KA and Connor, C (2003) Submarine melting at the terminus of a temperate tidewater glacier, LeConte Glacier, Alaska, U.S.A. Ann. Glaciol., 36 (doi: 10.3189/172756403781816374)

Motyka, RJ and 5 others (2011) Submarine melting of the 1985 Jakobshavn Isbræ floating tongue and the triggering of the current retreat. J. Geophys. Res., 116(F01007) (doi: 10.1029/2009JF001632)

Motyka, RJ, Dryer, WP, Amundson, J, Truffer, M and Fahnestock, M (2013) Rapid submarine melting driven by subglacial discharge, LeConte Glacier, Alaska. Geophys. Res. Lett., 40, 1-6 (doi: 10.1002/grl.51011)

Nienow, P, Hasholt, B and Willis, I (1998) Seasonal changes in the morphology of the subglacial drainage system, Haut Glacier D'Arolla, Switzerland. Earth Surf. Process. Landforms, 23, 825-843

Nye, JF (1969) A calculation on sliding of ice over a wavy surface using a Newtonian viscous approximation. Proc. R. Soc. Lond. A, 311, 445-467

O'Leary, M and Christoffersen, P (2013) Calving on tidewater glaciers amplified by submarine frontal melting. Cryosphere, 7, 119-128 (doi: 10.5194/tc-7-119-2013)

Rennermalm, AK and 7 others (2013) Evidence of meltwater retention in the Greenland ice sheet. Cryosphere, 7(5), 1433-1445 (doi: 10.5194/tc-7-1433-2013)

Rignot, E and Kanagaratnam, P (2006) Changes in the velocity structure of the Greenland ice sheet. Science, 311(5673), 986-990 (doi: 10.1126/science.1121381)

Rignot, E, Koppes, M and Velicogna, I (2010) Rapid submarine melting of the calving faces of West Greenland glaciers. Nat. Geosci., 3 (doi: 10.1038/NGEO765)

Röthlisberger, H (1972) Water pressure in intra- and subglacial channels. J. Glaciol., 11(62), 177-203

Sasgen, I and 8 others (2012) Timing and origin of recent regional ice-mass loss in Greenland. Earth Planet. Sci. Lett., 333, 293303 (doi: 10.1016/j.epsl.2012.03.033)

Schild, KM and Hamilton, GS (2013) Seasonal variations of outlet glacier terminus position in Greenland. J. Glaciol., 59(216) (doi: 10.3189/2013JoG12J238)

Schoof, C (2010) Ice-sheet acceleration driven by melt supply variability. Nature, 468, 803-806 (doi: 10.1038/nature0918)

Schrama, EJO and Wouters, B (2011) Revisiting Greenland ice sheet mass loss observed by GRACE. J. Geophys. Res., 116, B02407 (doi: 10.1029/2009JB006847)

Sciascia, R, Straneo, F, Cenedese, C and Heimbach, P (2013) Seasonal variability of submarine melt rate and circulation in an East Greenland fjord. J. Geophys. Res., 118, 2492-2505 (doi: 10.1002/jgrc.20142)

Selmes, N, Murray, T and James, TD (2011) Fast draining lakes on the Greenland ice sheet. Geophys. Res. Lett., 38(L15501) (doi: 10.1029/2011GL047872)

Shepherd, A and 46 others (2012) A reconciled estimate of ice-sheet mass balance. Science, 338(6111), 1183-1189 (doi: 10.1126/ science.1228102)

Slater, DA, Nienow, PW, Cowton, TR, Goldberg, DN and Sole, AJ (2015) Effect of near-terminus subglacial hydrology on tidewater glacier submarine melt rates. Geophys. Res. Lett., 42, 2861-2868 (doi: 10.1002/2014GL062494)
Sole, AJ and 6 others (2011) Seasonal speedup of a Greenland marine-terminating outlet glacier forced by surface meltinduced changes in subglacial hydrology. J. Geophys. Res., 116(F03014) (doi: 10.1029/2010JF001948)

Stott, TA and Grove, JR (2001) Short-term discharge and suspended sediment fluctuations in the proglacial Skeldal River, north-east Greenland. Hydrol. Process., 15(3) (doi: 10.1002/hyp.156)

Straneo, F and Heimbach, P (2013) North Atlantic warming and the retreat of Greenland's outlet glaciers. Nature, 504 (doi: 10.1038/ nature12854)

Straneo, F and 6 others (2011) Impact of fjord dynamics and glacial runoff on the circulation near Helheim Glacier. Nat. Geosci., 4, 322-327 (doi: 10.1038/ngeo1109)

Straneo, F and 8 others (2012) Characteristics of ocean waters reaching Greenland's glaciers. Ann. Glaciol., 53(60), 202-210 (doi: 10.3189/2012AoG60A059)

Sundal, AV and 5 others (2011) Melt-induced speed-up of Greenland ice sheet offset by efficient subglacial drainage. Nature, 469, 521-524 (doi: 10.1038/nature09740)

Sutherland, DA and Straneo, F (2012) Estimating ocean heat transports and submarine melt rates in Sermilik fjord, Greenland, using lowered acoustic Doppler current profiler (LADCP) velocity profiles. Ann. Glaciol., 53(60), 50-58 (doi: 10.3189/2012AoG60A050)

Tedstone, AJ and Arnold, NS (2012) Automated remote sensing of sediment plumes for identification of runoff from the Greenland ice sheet. J. Glaciol., 58(210), 699-712 (doi: 10.3189/ 2012JoG11J204)

van As, D and 10 others (2014) Increasing meltwater discharge from the Nuuk region of the Greenland ice sheet and implications for mass balance (1960-2012). J. Glaciol., 60(220), 314-322 (doi: 10.3189/2014JoG13J065)

Van den Broeke, M and 8 others (2009) Partitioning recent Greenland mass loss. Science, 326, 984-986 (doi: 10.1126/ science.1178176)

Van der Veen, CJ (2007) Fracture propagation as a means of rapidly transferring surface meltwater at the base of glaciers. Geophys. Res. Lett., 34(L01501) (doi: 10.1029/2006GL028385)

Van Meijgaard, E and 6 others (2008) The KNMI regional atmospheric climate model RACMO version 2.1. KNMI Technical Report 302. Royal Netherlands Meteorological Institute, De Bilt, Netherlands, 43 pp.

Vieli, A and Nick, FM (2011) Understanding and modeling rapid dynamic changes of tidewater outlet glaciers: issues and implications. Surv. Geophys., 32, 437-458 (doi: 10.1007/s10712-0119132-4)

Walters, RA, Josberger, EG and Driedger, CL (1988) Columbia Bay, Alaska: an 'upside down' estuary. Estuarine, Coastal Shelf Sci., 26 (6), 607-617 (doi: 10.1016/0272-7714(88)90037-6)

$\mathrm{Xu}, \mathrm{Y}$, Rignot, E, Menemenlis, D and Koppes, M (2012) Numerical experiments on subaqueous melting of Greenland tidewater glaciers in response to ocean warming and enhanced subglacial discharge. Ann. Glaciol., 53(60) (doi: 10.3189/2012AoG60A139)

$\mathrm{Xu}, \mathrm{Y}$, Rignot, E, Fenty, I, Menemenlis, D and Flexas, MM (2013) Subaqueous melting of Store Glacier, west Greenland from three-dimensional, high-resolution numerical modeling and ocean observations. Geophys. Res. Lett., 40, 4648-4653 (doi: 10.1002/grl.50825)

Zwally, HJ and 5 others (2002) Surface melt-induced acceleration of Greenland ice-sheet flow. Science, 297(218) (doi: 10.1126/ science.1072708) 